\title{
Modernisation of the Russian Energy Sector: Constraints on Utilising Arctic Offshore Oil Resources
}

\author{
PAMI AALTO
}

\begin{abstract}
This essay examines the modernisation of the Russian energy sector as revealed in the case of Arctic offshore oil. The Russian actors involved have various interests but their simultaneous realisation is impeded by the structural constraints within the policy environment of Arctic offshore oil projects. Russia's foreign policy choices vis-à-vis Ukraine, leading to sanctions targeting Arctic oil projects, and global oil market developments amplify the constraints on the resource geographical, financial, institutional and ecological dimensions of the policy environment or structure. This delays Arctic offshore oil projects, and hampers the oil industry's modernisation and its capacity to generate income for Russia's overall modernisation.
\end{abstract}

MANY ANALYSTS SUGGEST THAT RUSSIA'S MODERNISATION must be based on the rents accruing from the country's energy sector (Gaddy \& Ickes 2013, pp. 1-2; Grigoriev 2013, p. 5; Malle 2013, p. 99). This is because of the dominance of the energy sector in Russia's economy. It is the most competitive sector and consequently best positioned to generate the financial resources for Russia's overall modernisation. In turn, the energy sector itself must be an integral part of the country's modernisation, bearing in mind that Russia's energy intensity is more than twice that of Norway and a third higher than Canada's, both of which are also industrialised, large energy producing countries exposed to Arctic and sub-Arctic climates (EIA 2014a). ${ }^{1}$ Energy exports account for about a half of the Russian state budget and for two thirds of exports. In 2013, oil made up 33\% of the value of Russia's exports, oil products $21 \%$ and natural gas $14 \%$

This essay is part of the Finnish-Japanese project 'Russia's Final Energy Frontier-Sustainability Challenges of the Russian Far North' (Academy of Finland, Japanese Society for the Promotion of Science, V-P. Tynkkynen/S. Tabata, 2014-2016), and is funded by the Centre of Excellence on 'Choices of Russian Modernisation' (Academy of Finland/Kivinen, 2012-2017) and the project 'Energy Policy in European Integration' (Academy of Finland/Aalto, 2011-2015). For extensive assistance in compiling and formatting the material I would like to thank Iida Jaakkola, Pallavi Pal and Julia Simpanen, and for commentary, Terry Cox, Markku Kivinen, Andrei V. Belyi and Andrey A. Konoplyanik.

${ }^{1}$ Note, however, that the effect of the cold climate is stronger in Russia than in Canada or Norway (Gaddy \& Ickes 2013, pp. 34-47).

ISSN 0966-8136 print; ISSN 1465-3427 online/16/100038-26 ㄷ 2016 The Author(s). Published by http://dx.doi.org/10.1080/09668136.2015.1113509 Taylor and Francis.

This is an Open Access article distributed under the terms of the Creative Commons AttributionNonCommercial-NoDerivatives License (http://creativecommons.org/licenses/by-nc-nd/4.0/), which permits non-commercial re-use, distribution, and reproduction in any medium, provided the original work is properly cited, and is not altered, transformed, or built upon in any way. 
(EIA 2014b). With high oil prices during most of the past decade, the energy sector has boosted Russia's state budget, increased the state's redistributive capacities, and financed the ongoing rebuilding of the armed forces, while it has also helped to improve the welfare of most Russian citizens and to reinvigorate the national identity after the turbulent and humiliating 1990s.

Alongside the energy sector's salience and the widely agreed benefits it brings, the consequent dependence on oil prices implies risks. Most recently these risks materialised in winter and autumn 2014 . Oil prices fell below $\$ 50$ per barrel, only returning to $\$ 50-60$ per barrel by summer 2015 and were expected to stay low for the next one to three years due to global oversupply in a situation where Russia's 2014 state budget was balanced at prices of around $\$ 100$ per barrel. In addition, Russia's energy sector suffered from the economic, financial and political sanctions gradually imposed by the USA and the EU since spring 2014 due to Russia's annexation of Crimea and its involvement in the ensuing war in eastern Ukraine. The sanctions denied Russia access to credit and to Arctic and offshore energy technology. Australia, Canada, Japan, Norway, Switzerland and Ukraine also joined the sanctions regime.

In this essay the interlinked problems of Russia's modernisation, in particular the internal modernisation of its energy sector, and the consequences of low oil prices combined with the sanctions imposed on Russia, are explored by means of a case study of Russian Arctic offshore oil resources. Some of the major modernisation efforts undertaken by Russia target the energy sector, associated industries and services. The consecutive energy strategies of Russia since the early 2000s simultaneously stress the potential of the Arctic, while in the highly complex offshore oil projects in this remote and inhospitable region innovations are much needed in technologies, business models and institutions, and to curb ecological risks.

To address these interlinked problems, the research question in this essay is: can Russian Arctic offshore oil projects contribute to the modernisation of the energy sector? The investigation proceeds in the second section of this essay, where assumptions guiding the analysis are formed on the basis of the existing literature. In the third section Russia's energy strategies and Arctic strategies are examined in order to scrutinise the assumed profit generation and fiscal interests alongside the energy sector's modernisation needs as perceived by Russian actors. These interests are examined in the wider context of the foreign policy and social interests of the Russian state and its oil regions. The analysis is pursued by applying structuration theory assuming multiple actors and interests whose prospects of realisation are shaped by the structures of which the actors form part and which they help to co-constitute by their actions (Aalto et al. 2012, 2014). ${ }^{2}$ In the fourth section the empirical analysis is concretised by focusing on the choices made by Russian actors in Arctic offshore oil projects to realise their interests, and on how these choices are mediated by the constraining and enabling qualities of the structures. The concluding discussion re-assesses the research question and the assumptions while also evaluating the wider prospects and problems of Russian modernisation as revealed through the case study of Arctic offshore oil.

The analysis is based on primary and secondary documents, briefs, news material and earlier research while also drawing on fieldwork visits in September 2014 to Murmansk and Arkhangel'sk, two cities in Northwest Russia striving to gain stronger positions in the servicing of the country's Arctic energy projects. The time period analysed runs from the publication 
of Russia's first energy strategy in 2003 to the most recent draft strategy of 2014. This period also encompasses the development of Russia's Arctic strategy in two iterations from 2008 to 2013 (Klimenko 2014, p. 3). This is a short period for Arctic energy projects, which often take at least two decades to enter production. However, this period features several crucial policy formulations and actual choices, permitting some conclusions regarding the capacity of Arctic offshore oil projects to contribute to the modernisation of Russia's energy sector and an assessment of some wider implications regarding Russian modernisation.

\section{Russia's modernisation, the energy sector and the Arctic}

The linkages between Russia's modernisation and resource dependence evoke some controversies in the existing debate. Some economists, proceeding from the position of the energy sector as the most competitive branch of the Russian economy, suggest that the capacity of the sector to generate revenue offsets the vulnerability to fluctuations in global oil prices. In this view, the real problem is the use made of the rents generated from the exploitation of energy resources. Particularly misguided policies include reinvesting these funds in the name of diversification in the defence or manufacturing sectors, which promise less growth than the energy sector (Gaddy \& Ickes 2010, 2013, pp. 24, 98-9). Some other economists discuss the extent to which the Russian economy shows signs of a 'resource curse' where concentrating on this sector yields less growth than in countries with similar income levels; or even symptoms of a 'Dutch disease', whereby the energy sector 'crowds out' other economic activities (Sutela 2012; Tabata 2012). ${ }^{3}$ The European Bank for Reconstruction and Development notes the difficulties Russian actors face in avoiding the risks of resource curse and Dutch disease. Despite some policy statements in favour of diversification since the mid-2000s, Russia's range of exports since the 1990s has consistently narrowed towards the energy sector, while in the regions producing energy exports the employment structure has specialised even more in favour of this sector. Such development leads to increasingly specialised capacities and skills not well connected to other sectors of the economy, causing further path dependence (EBRD 2012).

Beyond economics, some scholars suggest that the energy sector's dominant position impedes the state's wider modernisation prospects in political, social and cultural terms. This problem originates in the state's significant strategic interest in energy since Vladimir Putin's ascent to power in 1999. As a result, state institutions protect sovereignty and strive to centralise the country's institutions to obtain a tight grip over energy provinces (Averre 2013). Some suggest more specifically that the combination of the state's control over strategic sectors such as energy, and its failure to reduce corruption in the legal system, to protect property rights and to reform the political system largely undermined the efforts to modernise the economy initiated during Dmitry Medvedev's presidency of 2008-2012 (Wilson 2015, p. 154). Some lament that the state continues to pour resources into the costly building of excess energy export infrastructure, predominantly on grounds of political interests (Baev 2013, p. 124). By redistributing the energy rents to capital intensive infrastructure projects serving

${ }^{3}$ In the 'Dutch disease' industrial output decreases and the domestic currency strengthens, while real wages grow together with the service sector and public expenditure. In this way, the whole economy gradually loses its competitiveness. 
the interests of business coalitions, and to public sector salaries, pensions and benefits to support other groups in society, the state seeks to de-politicise the domestic society (Sakwa 2014, pp. 56-7). In short, Russia's modernisation and the energy sector are closely interlinked and are a part of complex economic and wider societal structures shaping the range of policy options.

This wide constellation of modernisation, the energy sector and the related structures and choices, is examined here in the more limited context of Arctic offshore oil informed by five assumptions.

The first assumption is that the income generated by the energy sector is crucial to the modernisation of Russia, especially in the short to middle term perspective (Bradshaw 2012, p. 216). In 2012, the Russian state institutions started postponing the targets announced by President Medvedev in 2009 for the diversification of the country's economy away from the energy sector (Malle 2013, p. 79). In other words, the capacity of the energy sector to generate income is so strong that the risks of redistributing it poorly, vulnerability to fluctuations of global oil prices and other risks ensuing from resource dependence are worth taking.

Secondly, the income from the oil and oil product segments represents the energy sector's key contribution to Russia's modernisation in the same short to middle term perspective. This is because of their current high share of Russia's energy proceeds and the expectation of relatively high export volumes being maintained until the 2020s.

Thirdly, in order to maintain income, Russian energy actors must exploit the Arctic oil resources, particularly those offshore, and especially when moving towards the middle to long term perspective. Although oil extracted from Russia's continental shelf is expected to cover only $5 \%$ of Russia's production by $2035,{ }^{4} 68 \%$ of Russia's Arctic oil is expected to be found offshore (Zolotukhin \& Gavrilov 2011, p. 901). Together with oil from new onshore Arctic and sub-Arctic fields it will be crucial to compensate for dwindling production in western Siberia, Bashkortostan, Komi and Tatarstan (Kryukov \& Moe 2013, p. 36; Bobylev 2014 , p. 20). Russian oil companies need constant production to maintain their investment programmes, operations and market positions, while the state needs their continued ability to generate taxable income in a capital intensive business that relies on predictability and operates with very long lead times (Kontorovich et al. 2010, p. 10).

Fourthly, in order to maintain income, Russian energy actors must exploit Arctic offshore oil resources especially with an eye to the transport diversification and market access advantages they offer. To transport Arctic offshore oil, energy companies can load tankers directly from the drilling platform, bypassing the Transneft-controlled pipeline network and avoiding transit states. The Murmansk region's ports on the ice-free Barents Sea can service the offshore platforms and host storage and terminals for loading large supertankers. Anticipating a melting sea ice cap as a result of climate change, tankers may well be able to use the Northern Sea Route to reach the expanding Asian markets. The prospects of widening maritime access would also facilitate the servicing of Arctic oil drilling platforms and other infrastructure in the Pechora and Kara Seas, which currently remain icebound in winter. These prospects can be contrasted to the eastern Siberian resources, which offer lower extraction costs, but which are land-locked and depend on pipelines (Kryukov \& Moe 2013, p. 40). The remaining

\footnotetext{
${ }^{4}$ 'Energeticheskaya strategiya Rossii na period do 2035 goda (osnovnye polozheniya)' (hereafter ES 2035), 2014, available at: http://minenergo.gov.ru/documents/razrabotka/17481.html, accessed 20 October 2014.
} 
untapped western Siberian resources, for their part, are limited in volume (Zolotukhin \& Gavrilov 2011, p. 909).

Fifthly, in order to maintain income levels, Russian energy actors must exploit Arctic offshore oil resources with an eye to modernising the country's energy sector to make it more innovative and competitive. In other words, the multiple constraints on the complex Arctic offshore oil projects which will be analysed below will force Russian actors to go for major competitiveness-enhancing innovations in exploration, extraction, production, transport and technology development; investment; the functioning of institutions together with national and international cooperation; and the management of ecological risks.

In short, it is assumed that Russia's modernisation in the short to middle term depends largely on the capacity of the oil industry to pursue its profit interests and eventually generate taxable income to serve the state's fiscal interests. Arctic oil projects support the profit and fiscal interests as they help to maintain production and provide incentives to the energy sector to modernise. Thus Arctic oil projects can support the energy sector's resilience and its long-term role vis-à-vis Russia's overall modernisation. Wider macroeconomic and sociopolitical questions beyond these assumptions, such as whether the income generated by means of Arctic oil projects is redistributed well, or whether it supports socially, politically or ecologically desirable forms of Russian modernisation, are bracketed here.

\section{The structuration of Russia's choices in the Arctic}

The application of structuration theory helps to systematise and enrich the gradually accumulating body of knowledge on Russia's Arctic oil projects. This includes studies conducted in different disciplines, for example on Russia's Arctic resources (Kontorovich et al. 2010; Zolotukhin \& Gavrilov 2011; Kryukov \& Moe 2013), on Russia's territorial claims on grounds of the United Nations Convention on the Law of the Seas (UNCLOS) to access the offshore resources (Dodds 2010; Koivurova 2011), and on Russian interests vis-à-vis international cooperation and the role of institutions in the utilisation of the resources (Kraska 2011; Hong 2012; Filimonova 2013; Keil 2013; Klimenko 2014), as well as the associated ecological risks (Lesikhina et al. 2007). However, there is a dearth of theoretical models to help to systematise existing knowledge on the resources, institutions and ecology. Simultaneously the role of finance and investment has been only little discussed. To offer a tool to bridge some of these gaps, a more theoretical structuration approach is proposed here. This will also facilitate the comparison of existing knowledge to other studies on Russian energy and modernisation.

Our theoretical model of the structuration of Russia's Arctic oil projects starts from the interests of the actors involved. The actors make choices on how to formulate and further their interests, and how to comprehend and assess the hierarchy of those interests, with the help of cognitive frames. In other words, frames serve as cognitive filters by which actors extract relevant information to help them make choices. The guiding hypothesis is as follows:

Several interests drive Russian actors in Arctic offshore oil projects and the Russian government, led by the president, is the main strategic actor aligning these interests with each other; as such an actor, the government faces the major task of creating and supporting the formation of sufficiently appealing frames capable of aligning at least some of the various interests in order to enable the concerted and well-coordinated development of Arctic offshore oil. 


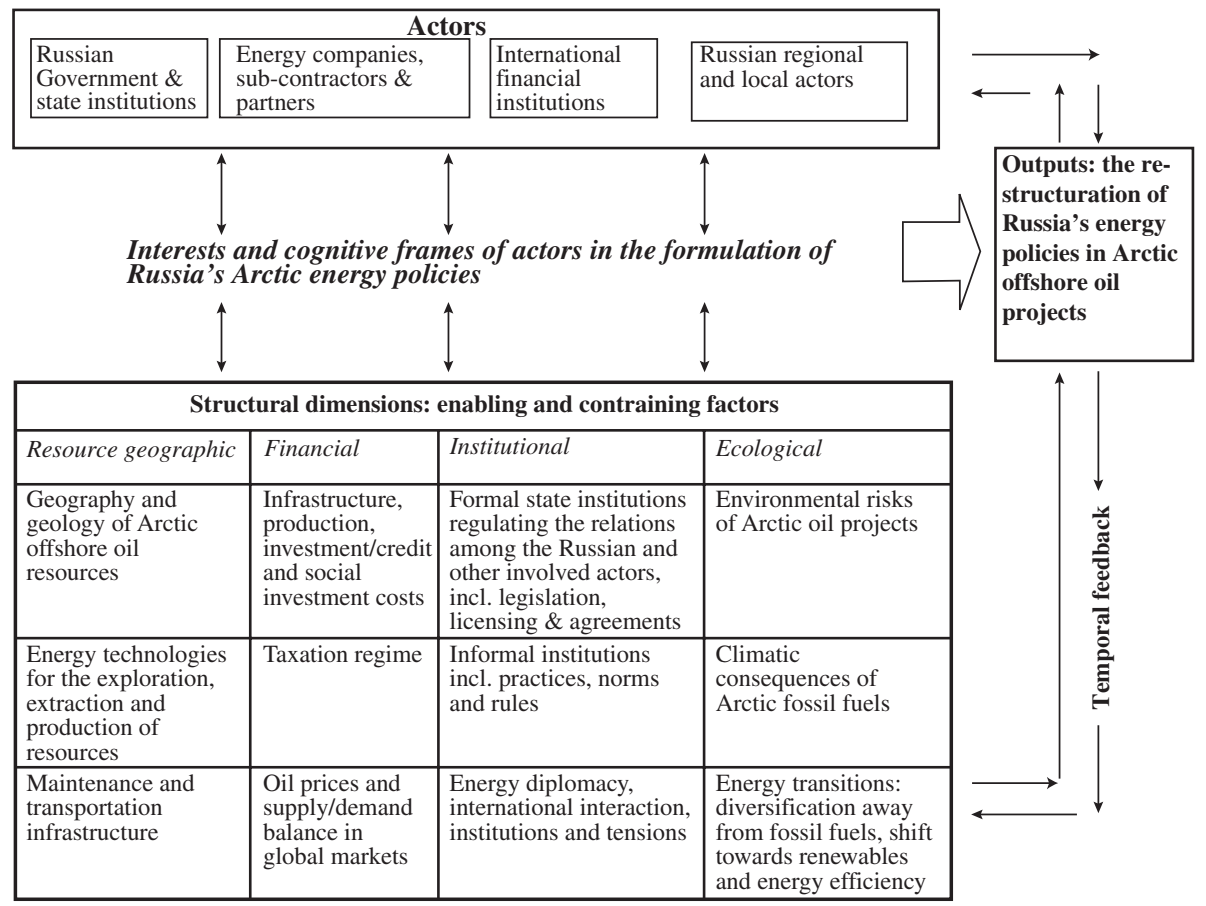

FIGURE 1. The Structuration OF Russia's ARCTIC OFFshore Oil Projects. Source: Created by the author.

In the light of the literature on Russia's modernisation cited above, the Government is indeed taking this strategic role very seriously, as witnessed in its grip over the economy, society and political system. The Russian Government, however, is constrained by the fact that the formation of interests and frames is contingent upon the actors' relevant structural contexts, which are conceptualised as policy environments. These, in turn, are modelled in terms of four structural dimensions the Russian actors need to master, or to take into account to realise their interests. They include what will be called the resource geographical, financial, institutional and ecological dimensions, which both constrain and enable the choices made by the actors. In other words, actors must make choices on what they want on the basis of what they know about those structural dimensions, while this knowledge is filtered through the cognitive frames they utilise.

The advantage of the model as thus summarised is its capacity to bring systematically into the analysis several types of actors and a wide range of structural features endowing them with resources and capabilities. It helps us to analyse what choices actors can realistically make and where they are most constrained (Aalto et al. 2012, 2014; see Figure 1). This ability of the structuration approach to include actors, structures and their interaction in the same model is crucial given the complex and multidimensional nature of energy policy (Bressand 2013, pp. 18-9). It is especially useful in the Arctic context, where we find several types of actors, levels of their aggregation and diverse problems within and across our four dimensions (Aalto \& Jaakkola 2015). We will next analyse Russian interests and frames and then proceed to the structural dimensions of the policy environment. 
Russian actors, interests and frames

Most studies so far reject any simple notions of an energy superpower frame prevailing widely in Russia. This frame emerged in the policy debate during the 2000s. It represented 'Russia' as a monolithic actor with strong interests in foreign policy influence to enhance the country's relative position vis-à-vis neighbours and in international relations in general by means of utilising energy deliveries and infrastructure for political leverage. The frame was strengthened by peaking oil prices and rising demand for oil and gas, which was edging market power in favour of Russian energy companies, which in turn were making enormous profits helping the state to meet its fiscal interests and invest in the strengthening state (Aalto et al. 2012, 2014). ${ }^{5}$

Several studies stress the political concerns such an energy superpower frame creates among Russia's energy customers. In the 2000s, at least five efforts by Lukoil, a private Russian oil company, to invest in infrastructure or acquire energy companies in Europe were rejected on the grounds of concerns that the company served the state's foreign policy interests (Poussenkova 2012, pp. 193-95). Excessively obvious pursuit of such interests through energy diplomacy risks destabilising producer-consumer relationships. It prompts customers to diversify their imports in order to reduce dependence on Russia (Godzimirski 2013, pp. 181-84). Such a diversification shift has in fact resulted from Russia's numerous energy related conflicts with important transit states Ukraine and Belarus since the mid-2000s (Balmaceda 2012). Russia's capacities to realise ambitious foreign policy interests were also hampered by the global financial and economic crisis of 2008-2009, which reduced the demand for Russian energy commodities in their main European markets. Since then the markets for Russian companies have tightened with increased production by OPEC countries and elsewhere, forceful market entry of new production from North America, as well as liquefied natural gas (LNG), unconventional oil and unconventional gas (Aalto \& Talus 2014; Kropatcheva 2014). In 2014, sinking global oil prices completed the list of severe structural constraints. In the future, on the oil products segment, new refineries in the Middle East will start competing with Russian ultra-light sulphur diesel (Smith 2015, pp. 35-41).

Within this more challenging policy environment Russian actors must respond to new pressures on several markets and product segments simultaneously. This cuts the prospects of one energy superpower framing uniting Russian actors. The financial sanctions of 2014 may result in a greater share of the energy sector ending up more closely linked to the state when state loans replace US and EU based finance (Gaddy \& Ickes 2014, p. 6). Although the sanctions may temporarily unify Russian actors, they will not facilitate the use of energy resources to serve political interests. Russia's resilience vis-à-vis sanctions depends heavily on continued income from the existing oil fields while the development of Arctic fields is constrained by the ban on exports of Arctic and offshore energy technologies, as will be analysed in more detail below. In this challenging environment the state needs to choose between measures associated with different forms of modernisation. These include the developmentalist model comprising tight control of political institutions, active industrial policy and some protectionism represented by President Putin, and the more competitionoriented and innovation-oriented plural model associated with Prime Minister Dmitry Medvedev (Sakwa 2014, pp. 39-44). The latter model did not, however, progress much

${ }^{5}$ See also Goldthau (2008), Rutland (2008). 
during Medvedev's presidency (Wilson 2015). Nevertheless, for any Arctic oil project to serve any modernisation aims, the main strategic actor, the Russian Government led by the president, must successfully not only identify and rank its own interests but also coordinate those of other actors involved (Tkachenko 2007; Aalto et al. 2012). What are these interests?

The Russian Government articulated a relatively stable set of interests from 2003 to 2014. The 2003 energy strategy made references to the modernisation of the energy sector to support economic growth and social development, and to Russia's active role as a participant in global energy markets (Ministry of Energy 2003, pp. 1, 12). The 2009 energy strategy of the Russian Government up to 2030 aimed to 'set up an innovative and efficient energy sector' (Government of the Russian Federation 2009, p. 15). It reiterated the interests of the 2003 strategy:

The objective of the energy policy of Russia is to maximise the effective use of natural energy resources and the potential of the energy sector to sustain economic growth, improve the quality of life of the population and promote strengthening of foreign economic positions of the country. (Government of the Russian Federation 2009, p. 10)

One crucial modernisation objective in the 2009 strategy is to increase oil refining, improve the quality of oil products and to develop oil related chemical industries (Government of the Russian Federation 2009, pp. 60-74).

In the current draft energy strategy until 2035 the overall aim is the 'qualitative renewal (modernisation) of the energy sector'. Energy consumption is to decrease alongside Russia's dependence on the sector, which for its part should stimulate new types of infrastructure by means of innovations. ${ }^{6}$ The 'complex modernisation' of the energy sector also presupposes the development of domestic markets, effectiveness, quality of commodities, diversification of export markets, commodities and products, and improvement of competitive capacities, while it should also support social and ecological responsibility. In the foreign policy sphere Russia 'as a responsible power understands foreign energy policy not only from the narrow point of view of exporters, maximising short-term gains, but as a means of resolving both national and international problems', promoting a global energy dialogue. ${ }^{7}$

From 2003 to 2014 the interests pertaining to the energy sector's modernisation became more pronounced and detailed in response to the shifts in the policy environments in Russia's main markets. Russia's 2013 strategy for developing the country's Arctic zone reiterates the interests in modernising the energy sector together with transport infrastructure, the rational use of resources, socio-economic development and 'ecological security', while it also features wider foreign policy interests including international cooperation and issues of military security. This broad similarity of interests articulated in the energy and Arctic strategies is logical given that Russia's Arctic strategy is intended to serve the realisation of national interests. ${ }^{8}$ Both the energy strategies and Arctic strategy name Russia's Arctic continental shelf, the Timan-Pechora region by the Arctic waters of the Pechora Sea, eastern Siberia and the Far East, among the chief sites of new development (Government of the Russian Federation

${ }^{6}$ ES 2035, p. 3; see also Ivanov (2014).

${ }^{7}$ ES 2035, pp. 8-9, 23.

${ }^{8}$ 'Strategiya razvitiya Arkticheskoi zoni Rossiiskoi Federatsii', Government of the Russian Federation, 20 February 2013, pp. 4-5, 19, available at: http://government.ru/news/432, accessed 4 October 2013. 
2009, pp. 67-9). ${ }^{9}$ The Government effectively made Gazprom and Rosneft privileged actors in the development of Arctic offshore resources on the grounds of the 2008 amendments to the Law on Subsoil Resources (Klimenko 2014, p. 4).

The modernisation of the energy sector is not, however, an objective in and of itself but rather has instrumental value vis-à-vis the more general set of interests and frames of the Russian actors. This constellation can be summarised as follows. The energy companies' profit interests are closely linked to the Government's fiscal interests. Together, the profit and fiscal interests are part of a wider business frame, which today is the most central frame aggregating Russian actors (Aalto et al. 2014). How does this frame work? The Government can improve the state's fiscal situation by collecting dividends as a shareholder from the annual profits of the partly state-owned energy companies Gazprom and Rosneft. It can also generate income from any further sales of the share stock of these companies and from the various taxes it collects from them (see below). Such an umbrella role of the business frame in bringing the various Russian interests together is crucial for generating resources for the modernisation of the energy sector and the state as a whole. For this reason only a few Russian actors actually question it. Yet this frame competes with other formulations.

Although the energy superpower frame has eroded if not dissolved, the Government retains interests in foreign policy influence. In the 2000s, altogether in 31 instances in 20 different countries, Russian actors cut energy supplies or threatened to do so (Orttung \& Øverland 2011). Russia also needs sufficient income from the energy sector in order to continue the modernisation of the armed forces (Godzimirski 2013, pp. 181-87). It seeks to protect Arctic energy projects by the creation of a new Arctic military force. The 2014 'crisis' in relations with its energy customers in Europe has forced Russia to strengthen its positions in Asian, and in particular Chinese markets. It also seeks common markets for energy carriers in the 'Eurasian economic space' as well as common regulation. ${ }^{10}$ Hence, the new Russian geopolitical frame seeks a balance between Europe, Asia and Eurasian integration.

The Government has an enduring interest in furthering social development with an eye to rent distribution, balance between the centre and the regions and overall maintenance of social order (Dusseault 2012). In its Arctic strategy, the Government seeks 'complex socio-economic development', including

improvement of the quality of life of the indigenous population and social level of economic activities in the Arctic, development of the resource base of the Arctic zone of the Russian Federation by means of the utilisation of forward-looking technology, modernisation and development of the infrastructure of the Arctic transport system. ${ }^{11}$

Russian regional actors, including those in the Arctic, share the interest in social development and compete among themselves for access to rents. This social frame links the Russian state with the interests of oil regions and other societal actors.

\footnotetext{
9'Strategiya razvitiya Arkticheskoi zoni Rossiiskoi Federatsii', Government of the Russian Federation, 20 February 2013, p. 8, available at: http://government.ru/news/432, accessed 4 October 2013. See also ES 2035 , p. 22.

${ }^{10}$ ES 2035, pp. 22-23.

${ }^{11}$ 'Strategiya razvitiya Arkticheskoi zoni Rossiiskoi Federatsii', Government of the Russian Federation, 20 February 2013, p. 8, available at: http://government.ru/news/432, accessed 4 October 2013. See also ES 2035, p. 4.
} 
A sustainability frame in terms of 'energy effectiveness' and 'ecological energy security' was implied in the 2003 strategy with special reference to the development of new Arctic fields (Ministry of Energy of the Russian Federation 2003, pp. 2, 5, 14). In the 2009 strategy energy efficiency and 'environmental safety' were reiterated (Ministry of Energy of the Russian Federation 2003, pp. 12, 16). In the 2014 draft strategy a wider interest in the sustainable development of the energy sector emerges, including social responsibility, ecological security and innovative development, as well as energy efficiency throughout the industry (Shadrina 2014, p. 60). ${ }^{12}$ The 2013 Arctic strategy for its own part widens the sustainability frame from the 2008 Arctic document (Sergunin 2015, p. 7). This sustainability frame links various interests related to managing some of the environmental consequences of the energy sector's development held by the Russian state, with those of affected regions, as well as local and environmental actors including NGOs.

How the Russian Government manages to combine this set of frames and interests in the planning, conduct and supervision of Arctic offshore oil projects is next examined in more detail. Policy choices are always made within the confines of the surrounding structure, by attempting a 'proper diagnosis' of it (Gaddy \& Ickes 2013, p. 1).

\section{How to realise interests in the complex environment of Arctic offshore oil projects}

\section{The resource geographical dimension}

This structural dimension is fundamental to the energy policies of any resource-rich countries like Russia. Here it pertains to the geography and geology of Russia's Arctic offshore oil resources, and exploration, extraction and production by modernising the technology of the energy industry as well as Russia's maintenance and transport infrastructure.

Regarding the geography and geology of resources, the Khanty-Mansi Autonomous Okrug has so far accounted for half of Russia's oil production (Filimonova 2013, p. 1) and as such has provided the resource base for Russia's modernisation. In the middle to long term, however, the geology is more promising in the Arctic fields of the Nenets Autonomous Okrug, the Yamalo-Nenets Autonomous Okrug and the Russian Arctic continental shelf, alongside eastern Siberia. Of the very little utilised Arctic offshore resources, depending on the estimate, some $70 \%$ are expected to be in the Arctic Barents and Kara Seas (Kryukov \& Moe 2013, p. 36), or some 40\% (Kontorovich et al. 2010, p. 6; see Table 1). However, the exploration coverage of the Russian Arctic Sea areas is some 25 times lower than that of Norway's continental shelf (Zolotukhin \& Gavrilov 2011, p. 902). In particular Russia's eastern Arctic Sea is very little explored. To improve the exploration coverage, different geological and geophysical methods should be used (Kontorovich et al. 2010, p. 4).

The US Geological Survey is a widely quoted, albeit contested source for estimating Arctic oil and gas reserves. According to Zolotukhin and Gavrilov (2011, p. 901), who assume Russia to control $70 \%$ of Arctic reserves, the survey leads us to believe that Russia's Arctic offshore contains some 46 billion tonnes of 'undiscovered' and 'technically recoverable' oil equivalent (Gautier et al. 2009, pp. 1175-76). This is lower than the 'best estimate' of the Russian Academy of Sciences, which is 97 billion tonnes of oil equivalent $\left(\mathrm{P}_{10}\right.$ level) in the 
TABLE 1

Main Oil Resources in Russia’s Barents, Kara and Pechora Seas.

\begin{tabular}{|c|c|c|c|}
\hline Field & Resource base & $\begin{array}{l}\text { Energy } \\
\text { carrier }\end{array}$ & Main company actors \\
\hline Pechora Sea & $\begin{array}{l}\text { Recoverable potential resources of oil and } \\
\text { gas } 4.9 \text { billion tonnes }\end{array}$ & & \\
\hline $\begin{array}{l}\text { Prirazlomnoe (discovered } \\
1989 \text {, commercial } \\
\text { production started in 2013) }\end{array}$ & $\begin{array}{l}\text { Recoverable reserves } 83.2 \text { million tonnes/72 } \\
\text { million tonnes (annual production max. } 6.6 \\
\text { million tonnes) }\end{array}$ & Oil & $\begin{array}{l}\text { Gazprom Neft Shelf } \\
\text { (license holder) and } \\
\text { some } 40 \text { international } \\
\text { companies }\end{array}$ \\
\hline $\begin{array}{l}\text { Dolginskoe (discovered } \\
\text { 1999, exploratory drilling } \\
\text { and well testing 2014) }\end{array}$ & $\begin{array}{l}\text { Recoverable reserves } 200 \text { million tonnes of } \\
\text { oil equivalent }\end{array}$ & Oil & $\begin{array}{l}\text { Gazpromneft-Sakhalin } \\
\text { (license holder), } \\
\text { Schlumberger, } \\
\text { Weatherford }\end{array}$ \\
\hline $\begin{array}{l}\text { Peschanoozerski/Kolgiev } \\
\text { Island (discovered 1982, } \\
\text { commercial production } \\
\text { 1987) }\end{array}$ & $\begin{array}{l}\text { Recoverable proved reserves (ABC1) } 7.5 \\
\text { million tonnes }\end{array}$ & Oil & $\begin{array}{l}\text { Zarubeshneft/Arctic } \\
\text { morneftegazrazvedka } \\
\text { JSC (license holder) }\end{array}$ \\
\hline $\begin{array}{l}\text { Medyn-more } \\
\text { (Medynskoye) (opened/ } \\
\text { discovered 1997) }\end{array}$ & $\begin{array}{l}\text { Potential oil reserves and resources } \\
\text { (geological/recoverable) } 700 \text { and } 163 \text { million } \\
\text { tonnes }\end{array}$ & Oil & $\begin{array}{l}\text { Rosneft (license } \\
\text { holder) (Medynsko- } \\
\text { Varandeisky) }\end{array}$ \\
\hline Pomorskoye & - & $\begin{array}{l}\text { Oil and gas } \\
\text { condensate }\end{array}$ & Rosneft (license holder) \\
\hline Severo-Gulyaevskoye & - & $\begin{array}{l}\text { Oil and gas } \\
\text { condensate }\end{array}$ & Rosneft (license holder) \\
\hline \multicolumn{4}{|l|}{ Kara Sea } \\
\hline Rusanovskoe & $\begin{array}{l}380.374 \text { million tonnes of potential oil } \\
\text { reserves }(\mathrm{C} 3) ; 119.475 \text { million tonnes of } \\
\text { potential recoverable oil }(\mathrm{C} 3) ; 240.374 \\
\text { billion cubic metres of proved gas }(\mathrm{C} 1) \text {, } \\
538.643 \text { billion cubic metres of probable gas } \\
(\mathrm{C} 2), 3.248 \text { trillion cubic meters of potential } \\
\text { gas }(\mathrm{C} 3) ; 4.822 \text { million tonnes of proved } \\
\text { condensate }(\mathrm{C} 1), 2.411 \text { million tonnes of } \\
\text { proved recoverable condensate }(\mathrm{C} 1), 10.806 \\
\text { million tonnes of probable condensate }(\mathrm{C} 2) \text {, } \\
\text { 5.403 million tonnes of probably recoverable } \\
\text { condensate }(\mathrm{C} 2)\end{array}$ & $\begin{array}{l}\text { Natural gas, } \\
\text { condensate } \\
\text { and oil }\end{array}$ & $\begin{array}{l}\text { Gazprom (license } \\
\text { holder) }\end{array}$ \\
\hline $\begin{array}{l}\text { Pobeda (University-1/ } \\
\text { Universitetskaya-1) } \\
\text { (discovery drilling 2014) }\end{array}$ & 1.3 billion tonnes of oil equivalent & Oil & $\begin{array}{l}\text { Rosneft (license } \\
\text { holder), joint venture } \\
\text { of Rosneft and } \\
\text { ExxonMobil (operator) } \\
\text { (ExxonMobil due to } \\
\text { sanctions suspended), } \\
\text { Nord Atlantic Drilling, } \\
\text { Schlumberger, } \\
\text { Halliburton, } \\
\text { Weatherford, Baker } \\
\text { Hughes, Trendsetter, } \\
\text { FMC }\end{array}$ \\
\hline Barents Sea & $\begin{array}{l}\text { Recoverable potential resources of oil and } \\
\text { gas } 22.7 \text { billion tonnes }\end{array}$ & $\begin{array}{l}\text { Natural gas, } \\
\text { condensate } \\
\text { and oil }\end{array}$ & \\
\hline
\end{tabular}

Sources: Lesikhina et al. (2007, pp. 5, 12-3) (Barents Sea, Pechora Sea and Medyn-more); 'Prirazlomnoe Oil Field', Gazprom, available at: http://www.gazprom.com/about/production/projects/deposits/pnm/, accessed 8 October 2015 (Prirazlomnoe); 'Gazprom Neft Begins Exploratory Drilling at the Dolginskoe Field in the Arctic', Gazprom, 30 June 2014, available at: http://www.gazprom-neft.com/press-center/news/1102432/, accessed 8 October 2015 (Dolginskoe); 'Gazprom Poised to Receive Licenses to Ludlovskoe, Rusanovskoe Fields (Part 2)', Interfax, 12 August 2013, available at: http://www.interfax.com/newsinf.asp?id=436629, accessed 8 October 2015 (Rusanovskoe); 'Lukoil to Sell Upstream Assets in Komi, Nenetsk \& Perm Areas', Rigzone, 16 April 2004, available at: http://www.rigzone.com/news/oil_gas/a/12351/Lukoil_to_Sell_Upstream_Assets_in_Komi_Nenetsk_Perm_ Areas, accessed 8 October 2015 (Kolgiev); 'State Commission on Reserves Confirms the Discovery of the Pobeda Field', Rosneft, 3 December 2013, available at: http://www.rosneft.com/news/today/03122014.html, accessed 8 October 2014 (Pobeda). 


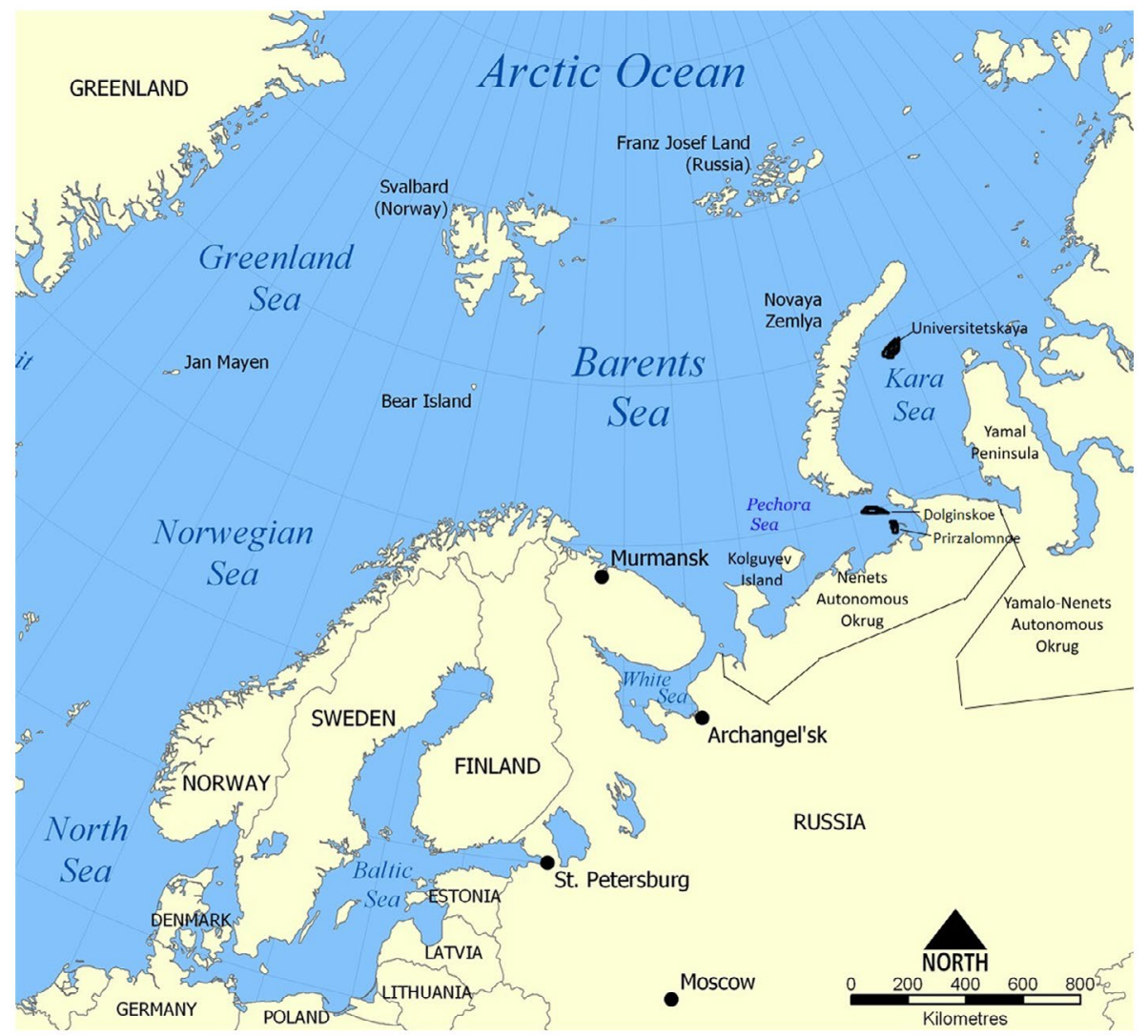

FIGURE 2. RUSSIA'S BARENTS AND KARA SEAS. Source: Adapted from Wikimedia Commons.

part of the Arctic Sea currently controlled by Russia - until the Arctic states reach a settlement on their extended continental shelf areas on the basis of the UNCLOS Treaty-and 142 billion tonnes in the Russian Arctic as a whole (Zolotukhin \& Gavrilov 2011, p. 901). ${ }^{13}$ According to Kim and Blank, 'all Russian figures derive from a grossly misunderstood reading' of the US survey (Kim \& Blank 2011, p. 306). The Siberian branch of the Russian Academy of Sciences, by contrast, condemns the survey as having 'nothing to do with geological reality', as it 'misleads nonspecialists and discourages investment in offshore ocean exploration' (Kontorovich et al. 2010, p. 9). The Russian framings of Arctic offshore oil commonly expect exploration with methods similar to those used in western Siberia to yield a larger resource base than Western estimates suggest. Regardless of these differences, the oil resource base is substantial, in particular in Russia's Barents and Pechora Seas, where some dozen potential oil fields have been discovered, at least six of which have commercial potential (Lesikhina et 
al. 2007; see Table 1). In September 2014, Exxon and Rosneft also found oil in the Kara Sea Universitetskaya-1 field, which was subsequently re-named Pobeda ('Victory') (see Figure 2).

The exploration, extraction and production of Russia's Arctic offshore oil resources is highly contingent upon the availability of advanced energy technology. However, the modernisation of the Russian energy industry already mentioned in Russia's energy strategy of 2003, is still a work in progress, especially as regards Arctic offshore drilling technology. As of 2015, the Prirazlomnoe field is the only Arctic offshore field in commercial production. It was discovered in 1989 at a depth of some 20 metres in the Pechora Sea, and is operated by the half state-owned Gazprom's subsidiary Gazprom Neft Shelf. The upper structure of the drilling platform was originally built in 1984 for operations in the North Sea. It was bought from KerrMcGee in 2002 and then, with major delays, refitted to suit the conditions prevailing in the Russian Arctic at the state-owned Sevmash yard in Severodvinsk on the White Sea. The installation of the platform on site took two and half years and was plagued by technical delays. During 2014 it delivered the first 200,000 tonnes of oil. Eventual annual production will reach some six million tonnes by 2020 (Staalesen 2014a). ${ }^{14}$ The ice-reinforced steel and concrete platform may also receive and store oil from nearby smaller fields for later development. Although the final platform is a part-product of the Russian industry, altogether 40 companies from 15 countries participated in its construction (Lesikhina et al. 2007). Half of the drilling equipment, services and technology is Western, and half of that is Norwegian (Staalesen 2014b). These features expose the platform's servicing to the effects of sanctions imposed in 2014 on Arctic and deep water offshore oil equipment.

The maintenance and transport infrastructure serving Russia's Arctic oil projects is also a work in progress. The Prirazlomnoe oil platform is maintained from 1,100 km away from the base of another Gazprom subsidiary, Gazflot, in Murmansk. ${ }^{15}$ Gazprom Neft plans new support facilities closer at the Timan Pechora oil transport hub Varandey (Moseev 2014a, p. 26). The company transports the oil from Prirazlomnoe to the Lukoil Belokamenka floating storage located in Kola Bay near Murmansk using Sovkomflot's maximum of 70,000 tonne ice-resistant shuttle tankers. The shallow waters of the Pechora Sea are frozen from November to June and hence require oil operators to use ice-breakers to reach the Belokamenka, which is converted from a former 340 metre tanker built by Mitsui in 1980. From the Belokamenka large supertankers can be uploaded to transport the oil to the European and other consumers.

The technology and transport constraints also hinder the exploration work of the Gazprom subsidiary Gazprom Neft-Sakhalin in the adjacent Dolginskoe field. The company started drilling in summer 2014 to a depth of some 35-55 metres with a view to eventually building two new Prirazlomnoe-type platforms to go into production by around 2020. Several Western service companies, such as Schlumberger and Weatherford, supplied the technology. Acknowledging the constraints imposed by the sanctions on the involvement of Western companies, in late 2014 Gazprom Neft agreed on joint operations with PetroVietnam in Dolginskoe, including exploration, development and sales of oil eventually to be produced even though PetroVietnam lacks any experience of Arctic offshore projects. ${ }^{16}$

\footnotetext{
${ }^{14}$ 'Third Oil Shipment from the Prirazlomnoe Field Delivered to Europe', Gazprom Neft, 17 November 2014, available at: http://www.gazprom-neft.com/press-center/news/1103547/, accessed 15 March 2015.

${ }^{15}$ Anonymous interview with business representative 1, Murmansk, 25 September 2014.

${ }^{16}$ 'International Cooperation on the Arctic Shelf', MurmanshelfInfo, 27 November 2014, available at: http://en.murmanshelf.ru/news/detail.php?ID=4900, accessed 15 March 2015.
} 
Rosneft's Arctic offshore oil operations are so far limited to exploration in its licensed blocks of the Kara and Barents Seas, while it also has licences for work in the Chuckhi and Laptev Seas in Russia's eastern Arctic. Working in this hostile Arctic geography with largely unknown geology, Rosneft is even more impeded by the technology and transport constraints mentioned above, which have been further exacerbated by the sanctions. In 2014 Gazprom offered its Arkticheskaya platform and further support to Rosneft, which by early autumn 2014 was left short of infrastructure and technology upon the withdrawal of its partner Exxon from all projects in the Kara Sea. The tightening of sanctions also halted Rosneft's cooperation with ENI and Statoil. ${ }^{17}$ Some $90 \%$ of the offshore exploration technologies used in Russia are imported (Moseev 2014b). In the Russian energy industry overall, the share of technology imports is some 20\% (Ivanov 2014). In January 2015, Rosneft froze its Roslyakovo shipyard project for three to five years. The company planned this to serve its Arctic offshore operations and to employ some 1,500 workers in the Murmansk region, while regional actors expected some 2,000 new jobs (Staalesen 2015). ${ }^{18}$ Roslyakovo was part of an extensive cooperation package announced with the Murmansk region in summer 2014. For that purpose, Roslyakovo was released from its status as a closed military territory. ${ }^{19}$

In summary, in these Arctic offshore oil projects the Russian energy industry advances the modernisation objectives set for it in the Russian energy strategies by using predominantly Western technologies, the availability of which became seriously constrained by the sanctions of 2014. Gazprom cooperates with several international companies in the Pechora Sea relatively close to the shoreline by adapting established Western technologies to Russian Arctic conditions and utilising the available Russian materials with less added value such as construction industry products, for example concrete structures and ships, and by commissioning some services from Russian companies. Rosneft generally operates further away from the coast, in the deeper waters of the Barents, Pechora and Kara Seas and consequently needs more innovations and international cooperation. It declared its intention to continue its seismic work after the withdrawal of Exxon, ENI and Statoil. However, the development of the Universitetskaya/Pobeda field is to be delayed until 2016 due to the absence of a drilling rig.

For some Russian observers, 'the sanctions do not represent a threat to Russia but an opportunity. They are a challenge which will even help the Russian industry to become stronger' ${ }^{20}$ Others expect the sanctions to reduce Russia's oil output by between $5 \%$ and $10 \%$. Additionally, the capacity of the Russian industry to 'russify' technology and services is hampered by the lack of research and development investment when oil prices were high in the mid-2000s. A further constraint is the lack of constant, timely enough flow of information between the companies and their suppliers on the requirements before tenders are published

\footnotetext{
${ }^{17}$ 'Itar-Tass: Russia’s Gazprom Ready to Help Oil Giant Rosneft with Arctic Drilling', Natural Gas Europe, 7 October 2014, available at: http://www.naturalgaseurope.com/gazprom-rosneft-arctic-drilling, accessed 15 March 2015.

${ }^{18}$ Anonymous interview with business representative 2, Murmansk, 24 September 2014.

${ }^{19}$ 'Russia's President Vladimir Putin has signed a decree that will relieve the settlement of Roslyakovo outside Murmansk of its status as closed military town. Rosneft has ambitious plans for the local shipyard', MurmanshelfInfo, 3 September 2014, available at: http://en.murmanshelf.ru/news/detail.php?ID=4876, accessed 15 March 2015.

${ }^{20}$ Anonymous interview with a business representative, Arkhangel'sk, 27 September 2014.
} 
(Moseev 2014b, pp. 7-8). To address the mounting constraints on the resource geographic dimension, in spring 2014, Rosneft bought the Russian and Venezuelan operations of the service company Weatherford. In October 2014, the Government founded the service company $\mathrm{RBC}$ with the intention to replace the Western companies (Kramer 2014).

\section{The financial dimension}

The financial dimension pertains to the costs related to infrastructure, production and investment, including access to credit and expectations for social investment by the regions hosting energy projects. In addition it comprises the taxation regime, and oil prices including the supply and demand balance in the global markets.

The construction costs of the Prirazlomnoe platform were some $\$ 800$ million. ${ }^{21}$ The final costs of the project are estimated to be between $\$ 2.5$ billion and $\$ 3$ billion (Klimenko 2014, p. 5; Staalesen 2013). Extraction costs some $\$ 40$ per barrel (Klimenko 2014, p. 7). Further costs include transport from Prirazlomnoe to the Belokamenka storage, lease of storage space, and the costs of ice-resistant shuttle tankers and the assistance of icebreakers (see above). Because Gazprom Neft exports Prirazlomnoe oil in crude form in the absence of oil refineries in the Russian Arctic, there are no further production costs. In turn, the prospects for Russian actors to add more value are thin.

In the Russian Arctic the investment costs are enormous. To realise its overall Arctic interests the Russian Government foresees state investments worth 623 billion rubles ( $€ 13.8$ billion) and 1.793 billion rubles (almost $€ 45$ billion) in total including private funds (Shalyov 2014). As part of this, Rosneft's exploratory operations with Exxon in the Kara Sea until autumn 2014 were covered mainly by Exxon on the strength of their agreements of 2011 and 2013. Exxon committed to funding the bulk of the finance for their initial joint operations in the Kara Sea and Black Sea, estimated at $\$ 3.2$ billion, and to covering the $\$ 200$ million initial cost of the two companies' Arctic Research Center, even though Exxon only controls $33.33 \%$ of these projects. ${ }^{22}$ In this way Rosneft limited its own investment needs as it was heavily in debt as a result of several investments such as the \$55 billion acquisition of TNK-BP in 2013.

The financial sanctions cut off access to Western credits which until then had financed some 70\% of Russia's oil projects, much of that coming from the EU area. In October 2014, Rosneft requested support of $\$ 49$ billion from the National Wealth Fund, roughly half of the fund's total volume. The State Duma only sanctioned the release of a tenth of the fund's volume to support Russian companies mostly in the energy and banking sectors. In December 2014 Rosneft was expected to receive backing for two projects in the Far East out of the seven proposals it submitted. ${ }^{23}$ Gazprombank received $\$ 770$ million from the same fund and VTB $\$ 1.8$ million. In short, while the financial sanctions resulted from the Russian Government's pursuance of its foreign policy interests in Ukraine, their unintended effects included the withdrawal of Western credit, compromising the state's fiscal interests.

\footnotetext{
${ }^{21}$ 'Prirazlomnoe Oilfield—, Russia', Offshore Technology Market and Customer Insight, 2015, available at: http://www.offshore-technology.com/projects/prirazlomnoye/, accessed 15 March 2015.

${ }^{22}$ 'Rosneft,Exxon MobilReachMilestonesinStrategicAgreement', OilandGas Journal,21 June2013, availableat: http://www.ogj.com/articles/2013/06/rosneft-exxonmobil-reach-milestones-in-strategic-agreement.html, accessed 15 March 2015.

${ }^{23}$ 'Russian Oil Major Rosneft to Get Aid from Welfare Fund for at least Two Projects-CEO', Tass, 16 December 2014, available at: http://tass.ru/en/economy/767335, accessed 15 March 2015.
} 
An alternative source of credit would be loans from Asia's emerging powers. For example, Rosneft has an agreement with the Chinese CNPC on developing resources in the Barents and Pechora seas (Filimonova 2013, p. 10); CNPC also controls $20 \%$ of Novatek's Yamal liquefied natural gas project. According to one analyst, European funding would, however, be preferred to Chinese credits:

[withdrawal of European financing] might kill, well not kill, but ruin and damage many of the structures in Russia. For industries or technologies or equipment, it's very much about financing. It's really hurtful for Russia and unfortunately we will see this again. I can just transmit the point of view of respected economists in Russia, that in case of Chinese funding it is like killing yourself in many ways ... the Chinese, they will never do something for free, just for good, as Europe can do. You cannot compare Europe and China in many aspects. Trust me it's the point of view of leading economists. They are saying we should be really careful with that funding from China. ${ }^{24}$

The energy companies are also expected to invest in social infrastructure, such as schools, kindergartens and other educational as well as sports facilities in the regions hosting their energy infrastructure. These non-commercial investments run counter to the companies' profit interests and are driven by the state and the region's joint social frame. These costs confuse the state's responsibilities as a rent income collector and redistributor. ${ }^{25}$ Yet the costs imposed onto the companies are relatively minor in relation to their total investments in large-scale infrastructure.

Acknowledging the various types of costs in the development of Russian Arctic offshore oil, in July 2012, the Russian Government granted Gazprom Neft a 50\% cut in the oil export tax for Prirazlomnoe oil similar to what the new East Siberian fields enjoy (Staalesen 2012). In addition, Arctic projects do not have to pay property tax or mineral extraction tax on the first 257 million barrels. Together these measures reduce the state's tax revenue from the normal 90\% rate to 50\%. ${ }^{26}$ From 2016, new Arctic oil projects will be exempted from the mineral export tax and will pay only a 5\% mineral extraction tax (Heininen et al. 2013).

Global oil prices, including the supply and demand balance and oil futures markets, in the last instance determine whether Russian companies can further their profit interests by means of Arctic offshore oil projects. They can influence the extraction, production and transport costs, which remain high. The Russian Government can adjust the taxation regime and influence the dividend policy of Gazprom and Rosneft considering the realisation of its fiscal and the social development interests. Global oil prices, however, represent a structural feature not easily controllable by Russian actors. Prirazlomnoe's production requires prices above between $\$ 80$ and $\$ 90$ to stay commercially profitable (Klimenko 2014, p. 7). As its oil is heavier than the normal Urals blend, the first deliveries were offered at a discount (Pettersen 2014). With global oversupply and prices consequently hovering between $\$ 50$ and $\$ 60$ per barrel between autumn 2014 and summer 2015, the Russian business frame including the realisation of the profit and fiscal interests was under serious pressure to restructure, as was

\footnotetext{
${ }^{24}$ Anonymous interview with a business liaison officer, Murmansk, 24 September 2014.

${ }^{25}$ Anonymous interviews with business representatives $1 \& 2$, Murmansk, 24-25 September 2014.

${ }^{26}$ 'Oil Field Options in Russia's Arctic Circle', Energy Digital, 15 November 2013, available at: http://www.energydigital.com/utilities/2610/Oil-field-options-in-Russia039s-Arctic-Circle, accessed 15 March 2015.
} 
the social frame that depends on the realisation of the profit and fiscal interests. This causes inevitable delays in Russia's Arctic oil projects.

\section{The institutional dimension}

The institutional dimension includes the structure of formal institutions regulating the relations among the Russian and other actors involved, comprising the legislation, licensing and agreements pertaining to Russia's Arctic oil. Importantly, this dimension also encompasses the structure of informal institutions - rules, practices and norms - which underpins the way in which formal institutions regulate relations among energy companies and their interaction with local, regional and governmental actors. Informal institutions are particularly influential in Russia (Ledeneva 2013). They frequently nullify the intended effects of reforms of formal institutions such as laws and administrative systems. As a result we identify various pathdependencies impeding policy changes and making incremental change likelier than rapid modernisation (North 1991; Granberg \& Nikula 2006). Finally, the conduct of energy diplomacy is also part of this dimension, referring to the structure of international interaction, institutions and tensions (Aalto 2014, 2015). ${ }^{27}$

Regarding formal institutions, the 2008 amendments to Russian subsoil legislation effectively made Gazprom and Rosneft privileged companies in Arctic offshore projects. They alone satisfied the conditions of five years of experience in the development of resources in the Russian continental shelf and over 50\% state ownership. Foreign companies cannot obtain new licences and have to consult the government upon acquiring $10 \%$ or more of a Russian company working in a strategic sector such as offshore oil. However, neither Gazprom nor Rosneft fulfils the requirements for geological prospecting set by the Ministry of Natural Resources and Ecology. In particular Rosneft, seriously affected by the recently emerging financial constraints described above, deems the requirements too high. Bashneft, Lukoil, Surgutneftegas and Zarubezneft, which operates a small field on Kolguyev Island in the Barents Sea, oppose and lobby against the privileging of Gazprom and Rosneft in Arctic offshore projects. To protect their interests Gazprom and Rosneft have cooperated in offshore development since the establishment of the JV Severmorneftegas in 2002 whose shares Gazprom acquired in 2005. Most recently, in 2012, they concluded a cooperation agreement on sharing infrastructure for offshore field development. However, this cooperation is compromised by their competition in liquefied natural gas development (Filimonova 2014, pp. 4-11).

For each new operation, Gazprom and Rosneft have to negotiate a trilateral formal agreement with local and regional administrations to obtain permits to acquire and develop the land necessary for their support operations, such as ports, including service to exploration, maintenance and export vessels, service to platforms, housing and social facilities for workers. In return they develop social and ecological infrastructure, and contribute to competence development in the educational institutions in Murmansk and Arkhangel'sk. They also have to present themselves in public hearings to seek the acceptance of local institutions for their projects: 'if the company enters the market here, they first have to get the agreement of the

\footnotetext{
${ }^{27}$ Importantly, even though these three main types of institutional structures contain elements of a social nature, in our structuration model they are analysed as part of the wider structural environment the actors face and which they have to 'filter' with the help of cognitive frames just like any other of the dimensions of structure we analyse.
} 
local population, our settlement, and secondly they have to do everything possible to make life better, they have a social responsibility towards the settlement' ${ }^{28}$ Statoil and Total also have such agreements on educational and social projects supporting the social development interests of the regional actors. ${ }^{29}$

Cooperation among the energy companies, and federal and regional formal institutions relies on the informal institutions, or practices and norms together accounting for the social frame that so crucially underpins Russian Arctic offshore oil projects. The prevalence of the social frame could also be discussed in terms of the institutional practices associated with developmentalism. The social and ecological interests of the regions depend on their fiscal interests in benefitting from the profits the companies make and the income their workers bring to the regional economy. Developmentalist economics notwithstanding, this set of interests compels the regions to compete against each other. At the same time, they have a division of labour of sorts. Murmansk provides the main support for the Pechora Sea operations, while about 100 companies in Arkhangel'sk work as sub-contractors on the projects of the Yamal Peninsula to which they are closer, in the areas of supplying cargo, ships and machine building, as well as construction. However, competence development is still incomplete despite four years of preparation and lessons learned from the cancelled Shtokman condensate project in the Barents Sea. ${ }^{30}$ On the governmental level the energy companies depend on federal strategies and support for transport infrastructure. For example, the federal transport hub project of the Murmansk region includes railways and terminals for coal and oil. ${ }^{31}$ In a word, Gazprom and Rosneft are well aware of the frames and interests of other Russian actors. Together with the international companies, they strive to do their share for the realisation of the social frame which has become more tangible in the recent iterations of Russia's energy and Arctic strategies.

Russia's energy diplomacy has the difficult task of addressing the unintended consequences of the realisation of Russia's foreign policy interests in Ukraine. These constraints concern both Russia's natural gas and oil industries in the Arctic and beyond and lead to Russia's customers and partners reconsidering their dependencies on Russian supplies and cooperation with Russian actors. The repercussions are not confined to the availability of advanced energy technologies or finance but also to the viability of Russia's system of redistributing energy rents, the realisation of the social frame including the delicate balance between the companies' profit interests, the state's fiscal interests and the regions' socio-economic interests and the sustainability frame. The regional actors whose social interests Russian Arctic oil projects serve, and who look for more of such impact, do not unequivocally support all foreign policy interests expressed by the Russian state institutions, and which led to the sanctions:

LNG technologies are mostly developed abroad. Underwater extraction complexes are neither used nor developed in Russia. Such technological difficulties prevail. For me as a businessman these seem some of the most complex issues.... Undoubtedly the prevention of oil spills is an acute question in

\footnotetext{
${ }^{28}$ Anonymous interview with a regional administration official, Murmansk, 24 September 2014.

${ }^{29}$ Anonymous interview with business representative 2, Murmansk, 24 September 2014.

${ }^{30}$ Anonymous interview with regional administration official, Murmansk, 24 September 2014; interview with business representative 1, Murmansk, 25 September 2014; anonymous interview with a business representative, Arkhangel'sk, 27 September 2014.

${ }^{31}$ Anonymous interview with a regional administration official, Murmansk, 24 September 2014.
} 
the Arctic which must be dealt with jointly. And now, I think, our political leaders should throw away all political ambitions for the sake of the security of the Arctic, its nature, people and its marine life. ${ }^{32}$

The constraints on international interaction ensuing from the Ukraine-Russia conflict, the associated sanctions imposed on the Russian Arctic energy industry and the regional actors thereby affected, as well as the tensions formed, are severe and not easily amended by means of energy diplomacy on the part of state institutions. The only positive feature in this respect is the continuing cooperation within the Arctic Council. In this situation Russian state institutions can realise their foreign policy interests in Ukraine but are more constrained beyond it. The associated constraints to the realisation of the profit, fiscal and social interests of Russian actors are an unintended net consequence of Russia's new unilateral foreign policy, and the related mismanagement among great powers with an interest in Ukraine. No single actor in the West or in Russia initially sought this outcome. As such it is an example of a failed diagnosis on the part of the Russian Government of the structure of which Russian energy diplomacy is part.

\section{The ecological dimension}

The ecological dimension refers here to the environmental risks of Arctic oil projects, the associated climate change effects, the long-term energy transitions targeting diversification away from fossil fuels, the promotion of energy efficiency and the development of renewable energy. In other words, serious constraints emerge on Russia's Arctic offshore oil projects when viewed through the ecological dimension. This is the case even though these projects simultaneously direct greater attention to the environmental side-effects of the industry, develop ecological expertise and are eventually intended to generate income for the modernisation of the Russian economy and energy industry which might make the country less dependent on fossil fuel resources in the long run.

The Russian legislation imposes several legal constraints on the oil industry in order to safeguard the ecological interests of the state and regions. The companies involved must present a plan on how oil removal would be conducted in the event of a spill and are responsible for paying for the repair of environmental damage. The centre for Emergencies and Elimination of Consequences of Natural Disasters (EMERCOM) of the Ministry for Civil Defence is responsible for the actual clean-up operations. It uses volunteers and utilises the expertise of scientific institutions which have developed a database on how to use chemicals to remove different types of oil, supported by the cross-border Kolarctic programme. ${ }^{33}$

However, because the Ministry's EMERCOM centre in Arkhangel'sk is several hours' journey away from the Pechora Sea oil extraction and loading facilities, the Ministry opened new centres with tasks in anti-oil spill activity in Naryan-Mar in 2013 and in Murmansk in 2015. Lukoil installed an emergency response oil removal system to protect its offshore pipelines and oil terminal near Varandei (Moseev 2014a, 2014b). On the Gazprom Prirazlomnoe platform, a zero discharge system is installed together with a seven seconds' emergency oil loading system intended to prevent oil spills (Petrova 2014). An anti-oil spill exercise is held annually with Norwegian organisations while further lessons are sought from the Norwegian experience of prevention (Banko 2012). On the level of the Arctic Council Member States, the Arctic Marine

\footnotetext{
${ }^{32}$ Anonymous interview with a business representative, Arkhangel'sk, 27 September 2014.

${ }^{33}$ Anonymous interview with business representative 1, Murmansk, 25 September 2014.
} 
Oil Pollution Preparedness and Response Agreement of 2013 directs attention to information exchange, mutual assistance, and calls for further bilateral and multilateral agreements. It lacks, however, any detailed standards regarding equipment, drilling techniques and safety measures. ${ }^{34}$ In short, Russian actors on several levels implement measures to protect ecological interests. Nevertheless, given the harsh Arctic conditions, which may prevent emergency work, many industry advisers recommend further measures to protect the companies' profit interests from potentially harmful environmental side effects and serious image losses (Eurasia Group 2013, pp. 24-6).

Regarding energy transitions, the Russian strategies have consistently called for more energy efficiency. The 2009 energy strategy set a target of a $4.5 \%$ share for the production and consumption of renewable energy by 2020 (Government of the Russian Federation 2009, pp. 110-11). According to the 2014 draft energy strategy, by 2035, the energy intensity of the GDP will have decreased by 50\%, and $\mathrm{CO}_{2}$ emissions by $75 \%$ compared to the level of 1990 (Ivanov 2014). This resembles the fossil fuels income supported energy transition attempted for example in Denmark, although the targets are more modest in Russia. According to the calculations made by the UNDP, Russia could reduce its energy consumption by increasing energy efficiency by $45 \%$ compared to the 2005 levels at a cost of $\$ 324-57$ billion (UNDP 2010 , p. 92). For this purpose it could acquire the necessary investment of $\$ 80-90$ billion a year from the export of fossil fuels which would otherwise have been sold on the domestic markets for lower profits. This virtuous cycle would serve several Russian interests simultaneously but presupposes a sufficient fossil fuel production volume as well as sufficient demand and high enough prices on the export markets. However, in the Arctic context, the effects of climate change may also hamper the development of energy infrastructure and increase the risks of environmental damage, while the utilisation of the region's resources will further exacerbate climate change (Bradshaw 2012, pp. 226-28). Overall, the constraints on the development of Russia's Arctic offshore oil, including the dwindling global demand and prices of 2014-2015, as well as the availability of investment capital and the relevant energy technology owing to the sanctions, represent a double-edged sword. On the one hand, the sustainability frame may be well served as more Arctic oil remains unexploited, while on the other, some of the expertise and equipment in the area of environmental protection in Arctic oil projects remains unavailable. Simultaneously the realisation of the Russian profit, fiscal and social interests is impeded.

\section{Discussion}

It was assumed in the second section of this essay that the development of Arctic offshore oil would, together with Arctic onshore and sub-Arctic oilfields, enhance the resource base of the Russian energy export industry and support its income generation capacity in the middle to long term perspective. Further, it was assumed that Arctic offshore oil would facilitate the diversification of transport routes and markets, and ultimately for its own part help the Russian energy industry to meet the overall modernisation objectives set for it in the country's energy strategies by virtue of the need to overcome the numerous constraints involved. The research

\footnotetext{
${ }^{34}$ See, 'Arctic Marine Oil Pollution Preparedness and Response Agreement', articles 5-13, 15 May 2013, Kiruna, Sweden, available at: http://www.arctic-council.org/eppr/agreement-on-cooperation-on-marine-oilpollution-preparedness-and-response-in-the-arctic/, accessed 15 March 2015.
} 
question concerned the modernisation of the energy industry in the context of Arctic offshore oil projects while it was hypothesised that aligning the various interests of the Russian actors involved is the major strategic task of the Russian Government.

The simultaneous realisation of the Russian energy companies' profit interests, the fiscal interests of the Government, and the social development and sustainability interests of the state and the regions, depends on a 'proper diagnosis' of the policy environment including its four structural dimensions. The difficulty is that each of the four dimensions examined in this essay comprises constraints capable, even on their own, of seriously hampering the realisation of the said set of interests. That Gazprom Neft shipped Russia's first Arctic offshore oil from Prirazlomnoe and sold it to the European markets in spring 2014 means that the Russian Government assessed the policy environment relatively successfully, and managed to aggregate the actors involved and aligned their interests. In other words, the Government managed to combine the business and social frames. Concomitantly it enjoyed favourable structural conditions beyond its own control especially on the financial dimension in the global oil markets in terms of high enough prices and demand meeting supply. Such was the situation of the Russian actors quite frequently from around the mid-2000s despite temporary shocks such as the global financial crisis in 2008-2009 and problems with transit countries.

By autumn 2014, the pursuit of Russia's foreign policy interests in Ukraine had caused several unintended consequences drastically restructuring the policy environment. The resulting sanctions imposed severe constraints on the resource geographical dimension by halting the supplies of western Arctic and deepwater oil technology, equipment and expertise. This questions the maintenance of Gazprom's existing Arctic offshore project and in particular Rosneft's pursuit of new projects. On the financial dimension the freezing of credit from the EU area and the USA forced the energy companies to halt, downsize or delay many of their Arctic operations. They also became dependent on Russian credit from the limited coffers of the National Welfare Fund and were forced to explore the possibilities of funding from countries like China and India. The Russian Government had to accept further risks in addition to the burden of the tax breaks previously granted to the companies, while oil regions lost some of the expected investments that would have helped to realise their social interests. On the institutional dimension the ability of the Russian Government to maintain an international coalition supporting the development of Arctic offshore oil fields has eroded while it has to enhance cooperation among domestic actors including Gazprom and Rosneft. On the ecological dimension some of the risks in frontier oil projects in the Russian Arctic offshore are delayed while Western cooperation expedient to the promotion of environmental technologies in oil exploration and extraction is impeded.

At the same time, structural processes beyond Russia's control, most markedly on the financial dimension, became less favourable for Russian actors as global oil market prices started to decrease rapidly in autumn 2014 and the demand and outlook for expensively produced Arctic oil worsened. This highlights the risks of resource dependence vis-à-vis global markets, especially when combined with a misreading of the policy environment and hence inadequate domestic policy planning. As a result of the structuration processes examined on the Russian domestic and wider international levels, Russian actors led by President Putin can only choose a more developmentalist model of active industrial policy. This entails developing a domestic service industry and energy technologies as well as increasing domestic credit. The restructured policy will most likely combine closer state supervision with some protectionism 
and import substitution measures. The time lag in the feedback from the likely changing policies back to the policy environment, however, is very long and not entirely under the Russian Government's control. Some of these new policy objectives were already implied in the draft energy strategy of 2014 and in the more vague modernisation objectives set in earlier strategies. The implementation of such new policies, it is fair to say, is still in its infancy given that Russian industries can so far deliver products like concrete structures, pipes and naval support vessels, but not as yet such advanced energy technology as is required. Even if the sanctions were lifted, we can expect Russian actors to prepare for similar situations in the future by promoting developmentalist policies. This could eventually offer a different modernisation path for the Russian state, industry and society than that seen during much of the post-Soviet era, which has been predominantly characterised by the globalisation and overall development of the Russian energy industry with the support of Western investment, cooperation and the exchange of best practices with leading companies in the Arctic and sub-Arctic areas.

In other words, the Russian Government prioritisation of the realisation of its foreign policy interests in Ukraine had several unintended consequences: it compromised the capacity of the business frame to bring the various Russian actors, their partners and related interests together to develop the country's Arctic offshore oil resources; it made the Russian energy industry more reliant on domestic technology, import substitution and funding, in addition to investment from Asia; it delayed the development of the Arctic oil offshore resources; it threatened tax income with profits delayed and further tax breaks possibly needed, and increased costs at a time when global oil prices were low. These unintended consequences further erode the appeal of the business frame. With this outcome, it is likely that the Russian state will struggle to generate the anticipated rents from Arctic offshore oil to support the modernisation of the country's energy industry as substantially as intended. However, the outcome may eventually support the development of the Russian domestic energy technology industry.

Russia's forced developmentalist choice of 2014-2015 in some ways resembles the policies by which North East Asian states aggressively develop their renewable energy sectors (Dent 2012), and thereby diversify their economies. Despite the similarities in the developmentalist policy measures, in the Russian case the equivalent effort is invested in the development of the fossil fuel sector without much diversification of the industry. For example, during the period 2004-2013, the share of refined oil in Russia's oil production increased from $42.5 \%$ to $53.1 \%$, but the depth of oil refining remained fairly low at 71.4\% (Bobylev 2014, p. 20). This means that Russia continues to export roughly speaking half crude oil, including crude oil from the Arctic offshore, and half relatively little refined oil products, none of which are so far from the Arctic. Owing to the need to support the oil industry's ongoing projects, and the related domestic banking sector, combined with the at least temporary withdrawal of Western technology, equipment, expertise and credit, it is difficult to foresee a fast-tracked modernisation of the Russian oil industry in the short to middle term. In countries like Norway, the development of offshore and Arctic high technology and expertise took several decades. It remains unclear whether the investments needed to build a modern domestic cluster of knowledge in Arctic and other advanced energy technologies will pay off for Russia. As of 2015, it seems that Russian actors are determined to choose that path in the absence of the 
previous, more international alternative for the development of this sector of the country's economy. Some Russian observers acclaim this policy shift as being long overdue.

Despite the dilemmas implied in the development of Russia's Arctic resources, the research results of this essay suggest that energy resources are not the main problem in Russia's modernisation as some of the debate on Russia's economic diversification might suggest. Rather the problem is the frames Russian actors use to weigh the policy environment through which the resource wealth can be actualised. Russian interests in foreign policy influence in particular cannot consistently be successfully combined with the business and social frames which are also prioritised in the Russian strategies. Importantly, frames consist of cognitively filtered socio-cultural interpretations and assumptions of the hierarchy and mutual dependencies of interests. This means that they are rooted in numerous informal institutions and as such not easily malleable. In consequence, in rapidly changing structural conditions such as those analysed in this essay, grossly sub-optimal policy choices become likely. Given Russia's constraints on the resource geographical, financial and institutional dimensions in particular, Russian actors can ill afford to misread the rules of the policy environment if they are first to regain and then sustain the income generating capacity of the oil sector. Should they fail to do that, a much less oil-based modernisation strategy is needed, but such a strategy is unlikely to be equally well supported by export income.

\section{University of Tampere}

\section{References}

Aalto, P. (2014) 'Institutions in European and Asian Energy Markets: A Methodological Overview', Energy Policy, 74.

Aalto, P. (2015) 'Russian Energy Diplomacy’, in Tiess, G., Majumder, T. \& Cameron, P. (eds) Encyclopedia of Mineral and Energy Policy (Berlin, Springer).

Aalto, P., Dusseault, D., Kennedy, M. D. \& Kivinen, M. (2014) 'Russia's Energy Relations in the East and West: Towards a Social Structurationist Approach to Energy Policy Formation', Journal of International Relations and Development, 17, 1.

Aalto, P., Dusseault, D., Kivinen, M. \& Kennedy, M. D. (2012) 'How Are Russian Energy Policies Formulated? Linking Actors and Structures of Energy Policy', in Aalto, P. (ed.) Russia's Energy Policies: National, Interregional and Global Levels (Cheltenham, Edward Elgar).

Aalto, P. \& Jaakkola, I. (2015) 'Arctic Energy Policy: Global, International, Transnational and Regional Levels', in Jensen, L. C. \& Hønneland, G. (eds) Handbook of the Politics of the Arctic (Cheltenham, Edward Elgar).

Aalto, P. \& Talus, K. (2014) 'Energy Markets in Europe and Asia: Too Many or Too Few Institutions', Energy Policy, 74, 1-3.

Averre, D. (2013) ‘The Modernisation Debate and Energy: Is Russia an “Energy Superpower”?', in Godzimirski, J. M. (ed.) Russian Energy in a Changing World: What is the Outlook for the Hydrocarbons Superpower? (Farnham, Ashgate).

Baev, P. (2013) 'Diversification, Russian-Style: Searching for Security of Demand and Transit', in Godzimirski, J. M. (ed.) Russian Energy in a Changing World: What is the Outlook for the Hydrocarbons Superpower? (Farnham, Ashgate).

Balmaceda, M. (2012) 'Russia's Central and Eastern European Energy Transit Corridor: Ukraine and Belarus', in Aalto, P. (ed.) Russia's Energy Policies: National, Interregional and Global Levels (Cheltenham, Edward Elgar).

Banko, Iu. (2012) 'Will Develop Arctic Shelf Together', MurmanshelfInfo, 23.

Bobylev, Y. (2014) 'Development Trends in Russia's Oil and Gas Sector', Russian Economic Developments, 6/2014.

Bradshaw, M. (2012) 'Russian Energy Dilemmas: Energy Security, Globalization and Climate Change', in Aalto, P. (ed.) Russia's Energy Policies: National, Interregional and Global Levels (Cheltenham, Edward Elgar).

Bressand, A. (2013) 'The Role of Markets and Investment in Global Energy', in Goldthau, A. (ed.) The Handbook of Global Energy Policy (Oxford, Wiley-Blackwell). 
Dent, C. M. (2012) 'Renewable Energy and East Asia's New Developmentalism: Towards a Low Carbon Future?', Pacific Review, 25, 5.

Dodds, K. (2010) 'Flag Planting and Finger Pointing: The Law of the Sea, the Arctic and the Political Geographies of the Outer Continental Shelf', Political Geography, 29, 2.

Dusseault, D. (2012) 'Russia's East and the Search for a New El Dorado: A Comparative Analysis of Russia's Kovytka, Sakhalin-2 and Chaiadinskoe Greenfield Projects', in Aalto, P. (ed.) Russia's Energy Policies: National, Interregional and Global Levels (Cheltenham, Edward Elgar).

EBRD (2012) 'Diversifying Russia: Harnessing Regional Diversity', European Bank for Reconstruction and Development, available at: http://www.ebrd.com/downloads/research/economics/publications/specials/ diversifying-russia.pdf, accessed 29 June 2015.

EIA (2014a) 'International Energy Statistics: Energy Intensity', Energy Information Administration, available at: http://www.eia.gov/cfapps/ipdbproject/IEDIndex3.cfm?tid=92\&pid=46\&aid=2, accessed 26 January 2014.

EIA (2014b) 'Oil and Natural Gas Sales Accounted for 68\% of Russia's Total Export Revenues in 2013', Energy Information Administration, 23 July, available at: http://www.eia.gov/todayinenergy/detail.cfm?id=17231, accessed 23 October 2014.

Eurasia Group (2013) 'Opportunities and Challenges for Arctic Oil and Gas Development', Washington, DC, The Wilson Center, available at: https://www.wilsoncenter.org/sites/default/files/Artic\%20Report_F2.pdf, accessed 22 October 2015.

Filimonova, N. (2013) 'Scramble for the Arctic Offshore Oil \& Gas Resources in Russia', in Heininen, L. (ed.) Arctic Yearbook 2013 (Northern Research Forum and University of the Arctic), available at: http://www. arcticyearbook.com/images/Articles_2013/FILIMONOVA_AY13_FINAL.pdf, accessed 1 July 2014.

Gaddy, C. G., \& Ickes, B. W. (2010) 'Russia after the Global Financial Crisis', Eurasian Geography and Economy, 51, 3 .

Gaddy, C. G. \& Ickes, B. W. (2013) Bear Traps on Russia's Road to Modernisation (London, Routledge).

Gaddy, C. G \& Ickes, B. W. (2014) 'Can Sanctions Stop Putin?', Brookings Institution, 3 June, available at: http://www.brookings.edu/research/articles/2014/06/03-can-sanctions-stop-putin-gaddy-ickes, accessed 15 March 2015.

Gautier, D. R., Bird, K. J., Charpentier, R. R., Grantz, A., Houseknecht, D. W., Klett, T. R., Moore, T. E., Pitman, J. K., Schenk, C. J., Schuenemeyer, J. H., Sørensen, K., Tennyson, M. E., Valin, Z. C. \& Wandrey, C. J. (2009) 'Assessment of Undiscovered Oil and Gas in the Arctic', Science, 324, May.

Godzimirski, J. M. (2013) 'Russian Energy: Summing Up and Moving Ahead', in Godzimirski, J. M. (ed.) Russian Energy in a Changing World: What is the Outlook for the Hydrocarbons Superpower? (Farnham, Ashgate).

Goldthau, A. (2008) 'Resurgent Russia? Rethinking Energy Inc', Policy Review, 147, March.

Government of the Russian Federation (2009) 'Energy Strategy of Russia for the Period up to 2030', Energeticheskaya Politika, available at: http://www.energystrategy.ru/projects/docs/ES-2030_(Eng).pdf, accessed 8 October 2015.

Granberg, L. \& Nikula, J. (2006) 'Förändring och kontinuitet på den ryska landsbygden', Nordisk Østforum, 20,3 .

Grigoriev, L. (2013) Russia's Economy: After Transformation, Before Modernisation, Valdai Discussion Club Analytical Report, Moscow, available at: http://vid-1.rian.ru/ig/valdai/Russian\%20economy\%20after\%20 transformation_ENG.pdf, accessed 22 October 2015.

Heininen, L., Sergunin, A. \& Yarovoi, G. (2013) 'New Russian Arctic Doctrine: From Idealism to Realism?', Valdai Discussion Club, available at: http://valdaiclub.com/russia_and_the_world/60220.html, accessed 15 March 2015.

Hong, N. (2012) 'The Energy Factor in the Arctic Dispute: A Pathway to Conflict or Cooperation?', Journal of World Energy Law and Business, 5, 1.

Ivanov, I. S. (2014) 'Innovative Potential of Russian Fuel and Energy Complex: Opportunities and Prospects', Ministry of Energy of the Russian Federation, available at: www.i-regions.org/(I_S_Ivanov)MoE\%20 Presentation.ppt, accessed 15 March 2015.

Keil, K. (2013) 'The Arctic_-A New Region of Conflict? The Case of Oil and Gas', Cooperation and Conflict, $49,2$.

Kim, Y. \& Blank, S. (2011) 'The Arctic: A New Issue on Asia's Security Agenda', Korean Journal of Defence Analysis, 23, 3.

Klimenko, E. (2014) Russia's Evolving Arctic Strategy: Drivers, Challenges and New Opportunities, SIPRI Policy Paper 42, September.

Koivurova, T. (2011) 'The Actions of the Arctic States Respecting the Continental Shelf: A Reflective Essay', Ocean Development and International Law, 42, 3. 
Kontorovich, A. E., Epov, M. I., Burshtein, L., Kaminskii, V. D., Kurchikov, A. R., Malyshev, N. A., Prischepa, O. M., Safronov, A. F., Stupakova, A. V. \& Suprunenko, O. I. (2010) 'Geology and Hydrocarbon Resources of the Continental Shelf in Russian Arctic Seas and the Prospects of Their Development', Russian Geology and Geophysics, 51, 1.

Kramer, A. (2014) 'The "Russification” of Oil Exploration', New York Times, 29 October, available at: http:// www.nytimes.com/2014/10/30/business/energy-environment/russia-oil-exploration-sanctions.html?_r=0, accessed 8 October 2015.

Kraska, J. (ed.) (2011) Arctic Security in an Age of Climate Change (Cambridge, Cambridge University Press).

Kropatcheva, E. (2014) 'He Who Has the Pipeline Calls the Tune? Russia's Energy Power against the Background of the Shale "Revolutions", Energy Policy, 66.

Kryukov, V. \& Moe, A. (2013) 'Oil Industry Structure and Developments in the Resource Base: Increasing Contradictions?', in Godzimirski, J. M. (ed.) Russian Energy in a Changing World: What is the Outlook for the Hydrocarbons Superpower? (Farnham, Ashgate).

Ledeneva, A. (2013) Can Russia Modernise? Sistema, Power Networks and Informal Governance (Cambridge, Cambridge University Press).

Lesikhina, I., Rudaya, I., Kireeva, A., Krivonos, O. \& Kobets, E. (2007) 'Offshore Oil and Gas Development in Northwest-Russia: Consequences and Implications', Bellona, available at: http://bellona.org/news/ uncategorized/2007-11-offshore-oil-and-gas-development-in-northwest-russia-consequences-andimplications, accessed 15 March 2015.

Malle, S. (2013) 'Economic Modernisation and Diversification in Russia: Constraints and Challenges', Journal of Eurasian Studies, 4, 1.

Ministry of Energy of the Russian Federation (2003) The Summary of the Energy Strategy of Russia for the Period up to 2020 (Moscow, Ministry of Energy of the Russian Federation).

Moseev, I. (2014a) 'Okrug Near Shelf', Sozvezdye Review, 19.

Moseev, I. (2014b) 'What's There in Stock to Substitute Imported Goods?', Sozvezdye Review, 21.

North, D. C. (1991) 'Institutions', Journal of Economic Perspectives, 5, 1.

Orttung, R. \& Øverland, I. (2011) 'A Limited Toolbox: Explaining the Constraints on Russia’s Foreign Energy Policy', Journal of Eurasian Studies, 2, 1.

Petrova, N. (2014) 'Gazprom Neft Moves to Optimise Prirazlomnoye Oil Field', Offshore Mag, 11 December, available at: http://www.offshore-mag.com/articles/print/volume-74/issue-11/arctic/gazprom-neft-movesto-optimize-prirazlomnoye-oil-field.html, accessed 15 March 2015.

Pettersen, T. (2014) 'Third Shipment of Prirazlomnoe Oil Delivered to Europe', Barents Observer, 18 November, available at: http://barentsobserver.com/en/energy/2014/11/third-shipment-prirazlomnoye-oil-deliveredeurope-18-11, accessed 15 March 2015.

Poussenkova, N. (2012) “They Went East, They Went West ...": The Global Expansion of Russian Oil Companies', in Aalto, P. (ed.) Russia's Energy Policies: National, Interregional and Global Levels (Cheltenham, Edward Elgar).

Rutland, P. (2008) 'Russia as an Energy Superpower', New Political Economy, 13, 2.

Sakwa, R. (2014) Putin Redux: Power and Contradiction in Contemporary Russia (London, Routledge).

Sergunin, A. (2015) 'Russian Strategy for Sustainable Socio-Economic and Environmental Development: Theory and Practice', paper presented in the seminar Sustainable Development of the Russian Far North and the Arctic, Tokyo, 31 January.

Shadrina, E. (2014) 'Russia's Natural Gas Policy toward Northeast Asia: Rationales, Objectives and Institutions', Energy Policy, 74.

Shalyov, A. (2014) 'Russian Arctic Awaiting Investments', Barents Observer, 24 January, available at: http:// barentsobserver.com/en/opinion/2014/01/russian-arctic-awaiting-investments-24-01, accessed 15 March 2015.

Smith, S. (2015) Russia's Oil Export Strategy: Two Markets, Two Faces, CIEP paper 01, available at: http://www. clingendaelenergy.com/inc/upload/files/CIEP_Paper_2015-01_Russia_web.pdf, accessed 29 June 2015.

Staalesen, A. (2012) 'Tax Benefits for Prirazlomnoye', Barents Observer, 18 June, available at: http:// barentsobserver.com/en/energy/tax-benefits-prirazlomnoye, accessed 15 March 2015.

Staalesen, A. (2013) 'Gazprom Neft Goes Offshore Arctic', Barents Observer, 28 February, available at: http://barentsobserver.com/en/energy/2013/02/gazprom-neft-goes-offshore-arctic-28-02, accessed 15 March 2015.

Staalesen, A. (2014a) 'First Oil from Prirazlomnoye', Barents Observer, 8 April, available at: http:// barentsobserver.com/en/energy/2014/04/first-oil-prirazlomnaya-08-04, accessed 15 March 2015.

Staalesen, A. (2014b) “"Prirazlomnaya” Goes Russian', Barents Observer, 16 September, available at: http:// barentsobserver.com/en/energy/2014/09/times-sanctions-prirazlomnaya-goes-russian-16-09 22, accessed 15 March 2015. 
Staalesen, A. (2015) 'Rosneft Puts Murmansk on Ice', Barents Observer, 6 January, available at: http:// barentsobserver.com/en/energy/2015/01/rosneft-puts-murmansk-ice-06-01, accessed 15 March 2015.

Sutela, P. (2012) The Political Economy of Putin's Russia (London, Routledge).

Tabata, S. (2012) 'Observations on Russian Exposure to the Dutch Disease', Eurasian Geography and Economics, 53, 2.

Tkachenko, S. (2007) 'Actors in Russia's Energy Policy towards the EU', in Aalto, P. (ed.) The EU-Russia Energy Dialogue: Europe's Future Energy Supplies? (Aldershot, Ashgate).

UNDP (2010) 'National Human Development Report in the Russian Federation 2009: Energy Sector and Sustainable Development', United Nations Development Programme, available at: http://www.undp.ru/ documents/NHDR_2009_English.pdf, accessed 8 October 2015.

Wilson, K. (2015) 'Modernization or More of the Same in Russia: Was There a “Thaw” Under Medvedev?', Problems of Post-Communism, 62, 3.

Zolotukhin, A. \& Gavrilov, V. (2011) 'Russian Arctic Petroleum Resources', Oil \& Gas Science and Technology, $66,6$. 